\title{
Segmentariedad política y sultanato. Los sultanes marroquíes Abdelaziz, Hafid y Yussef (1894-1927) y la política colonial francesa
}

\author{
Political Segmentarity and the \\ Sultanate: On the Moroccan \\ sultans Abdelaziz, Hafid and Yussef \\ (1894-1927) and French Colonial Politics
}

\section{JOSÉ ANTONIO GONZÁLEZ ALCANTUD*}

Resumen: El análisis segmentarista -alianzas y contraalianzas de segmentos de tribu - se inicia con Ibn Jaldún y su visión de las tribus norafricanas en el siglo XIV, pero se activa sobre todo desde los estudios de W. Robertson Smith y E. E. Evans-Pritchard a finales del siglo XIX y primera mitad del xx. Estas teorías han sufrido cierto descrédito en los años de la descolonización. En este artículo se estudia el periodo de 1894 a 1927 en Marruecos, correspondiente a los sultanes Abdelaziz, Hafid y Yussef, para volver sobre la tesis segmentarista, pero ahora aplicada no sólo al sistema tribal, sino al majzén mismo, y sobre todo a la política europea del momento en relación con el reino jerifiano. De esta manera, se recuperan las hipótesis segmentarias al sacarlas del estrecho marco anterior.

Palabras clave: segmentariedad; majzén; Muley Abdelaziz; Muley Hafid; Muley Yussef; Hubet Lyautey.

Recepción: 5 de noviembre de 2017. / Aceptación: 10 de julio de 2018.

* Universidad de Granada, jagalcantud@gmail.com 
Abstract: The segmentary analysis-alliances and rivalries among tribal factions-starts with Ibn Khaldun and his vision of North African tribes in the 14th century, but gains particular momentum following the studies of W. Robertson Smith and E. E. Evans-Pritchard at the end of the 19th century and the first half of the 20th. These theories have been discredited to a certain extent during the decolonization period. This article examines the period from 1894 to 1927 in Morocco, relating to the Sultans Abdelaziz, Hafid and Youssef, re-examining the segmentary thesis, but now applied not only to the tribal system, but to the Makhzen itself, and especially to the contemporary European politics of the time in relation to the Sherifian kingdom. In this way, the segmentary hypotheses are recovered, extracting them from the previously narrow framework.

Keywords: segmentarity; Makhzen; Mouley Abdalaziz; Moulay Hafid; Moulay Youssef; Hubert Lyautey.

\section{¿Finitud teórica de la segmentariedad?}

La teoría llamada "de la segmentariedad" ha gozado de gran predicamento en la antropología del mundo islámico. El segmento de linaje era una unidad más densa y extensa que el núcleo familiar, el cual poseía todas las características de la tribu. Constituía la estructura sobre la que se asentaban alianzas y contraalianzas en un juego de equilibrios que contribuía al mantenimiento del orden social frente a la tendencia a la disipación entrópica. Los conceptos de amistad y enemistad eran, pues, instrumentales, en función del juego estructural de los segmentos de tribu. La teoría de la segmentariedad se basa en los estudios del parentesco tribal africano y arabo-bereber fundamentalmente.

Se adjudica a Ibn Jaldún, en su Al Muqaddimab o Introducción a la historia universal, en el siglo XIV, la primera reflexión sobre el papel crucial de los linajes, y en particular de los segmentos de linaje, en la formación del juego de tensiones y equilibrios de las tribus nómadas. Ibn Jaldún, una excepción en su época y sobre todo en los siglos posteriores, emancipó el relato histórico de las pesadas genealogías que otorgaban legitimidad en la construcción de la autoridad en el islam y sometió el linaje a una interpretación "sociológica” a través del concepto de asabi- 
ya (عصــبـ) o solidaridad agnática (Jaldún, 1977; Hart, 1999). Ulteriormente, los primeros estudios sobre parentesco realizados en Arabia a finales del siglo XIX, debidos a W. Robertson Smith (1909; Eickelmann, 2003, pp. 47-78), incidieron en la misma dirección. A su vez, Smith fue retomado por E. E. EvansPritchard (1949) para explicar el funcionamiento de la sociedad islámica, como la de los sanussi de la Cirenaica libia. En el Marruecos francés, Robert Montagne (1930), en los años treinta, vio en esta teoría un recurso que facilitó la dominación colonial, en especial en el universo tribal bereber, bajo el dictado clásico del "divide y vencerás".

La teoría de la segmentariedad, que prevaleció en la escuela estructural-funcionalista británica, fue muy criticada a partir de la década de 1980, en particular en los medios antropológicos autóctonos magrebíes. En Marruecos se dijo, en síntesis, que pertenecía a un modo de ver las cosas puramente colonial, puesto que convertía a los "indígenas" en parte de un automatismo social que anulaba su voluntad (Rachik, 2012, pp. 163-188). El principal recusado fue Ernest Gellner (1969), que había analizado los linajes santos de morabitos y chorfas en relación con las funciones estructurales de intermediación en una sociedad segmentaria. Los ataques del historiador nacionalista Abdallah Laroui (1993; Hammoudi, 1974) a los "segmentaristas" se hicieron célebres. La propia escuela interpretativa de Clifford Geertz, muy relevante en Marruecos tras su estudio del bazar de Sefrou, dejó de lado la manera de ver los hechos sociales "segmentaristas" (Cefaï, 2003; Rabinow, 1992).

El funcionamiento del majzén, o poder real, instituido como entorno del sultán o sultaniya (ســــــانية), fue presentado como parte de ese juego entre segmentariedad tribal y centralización del poder. Varios trabajos politológicos fueron en esa dirección (Waterbury, 1975; Tozy, 2008; Leveau, 1985; González Alcantud, 2013a). El propio sistema de elección de sultán en Marruecos en la época alauita, a partir de finales del siglo xVII, donde la monarquía hereditaria no se imponía más que tímidamente, es muy representativo de esta situación. A ella contribuye la inestabilidad del país llamado siba, tribal e insumiso, y la propia doctrina islámica, que no resuelve el asunto de la legitimidad dinástica (Daïjt, 1989, pp. 38-57). 
La publicación histórica más elocuente para comprender el funcionamiento del majzén, o poder central marroquí nucleado en torno a las cinco ciudades imperiales, es la del etnógrafo e historiador Edmond Doutté (1909), de principios del siglo Xx. A esta reflexión hay que añadirle varios libros de memorias de viajeros occidentales que pudieron intimar con el entorno del sultán. Entre ellos hemos de citar al inglés Walter Harris (2012) y a los franceses Eugene Aubin (2004), Édouard Michaux-Bellaire (1908) y Gabriel Veyre (2008).

Al ser el sultán emir el moumenîn (أمســير المؤمنين) o "comendador de los creyentes”, la condición califal es extremadamente importante, ya que supone que los sultanes alauitas se situaban en la línea sucesoria directa del profeta. Razona Doutté (1909, p. 3) sobre los sistemas de elección y proclamación del emir: "Debe ser mayor, sano de cuerpo y de espíritu, instruido en la religión y originario de la misma tribu que el Profeta", es decir jerife, cherif, o chorfa en dialecto marroquí. Es el responsable de vigilar mediante la ley islámica o charia. El problema de la herencia en este grupo es que está regido por la genealogía. Para evitar el vacío de autoridad o las regencias, que son consideradas auténticos periodos de inestabilidad, el sultán puede dejar testamentariamente designado a su sucesor: " $\mathrm{El}$ acto de institución del sucesor es siempre llamado 'abd", arguye Doutté (p. 4). Se trata de evitar los problemas del harén. Los aspirantes pueden ser primogénitos o no, e hijos de mujeres legítimas o esclavas, si bien se observa cierto derecho de precedencia en la primogenitura.

El reconocimiento y la sumisión, amén de la genealogía, serían actos instituyentes externos: "El acto por el cual es reconocido, dirigido por los principales doctores (ulemas), es una bêa, palabra que significa igualmente 'contrato de venta' o 'de compra”" (Doutté, 1909, p. 3). O sea que, aunque fuese genealógicamente un heredero legítimo, debía ser ratificado por los ulemas y aclamado unánimemente por el pueblo a su entrada en la ciudad imperial. La herencia genealógica de los chorfa (أنشـراف), pero también la sumisión o beyâa (بَّنَ), son hechos fundamentales. Con esta última se produce "una declaración de sumisión irrevocable" que busca dar seguridad al sultán mediante la fidelidad (Mouline, 2016, p. 73). De ahí que el sultán esté 
lejos ser un monarca absoluto y se acerque más, según Doutté $(1909$, p. 4), a ser un "mandatario de sus correligionarios" que, en caso de propasarse en su mandato, puede ser depuesto.

Hasta ahí, señala Doutté, la ortodoxia, pero hemos de introducir la heterodoxia, que no es otra cosa que la aportación autóctona al concepto del poder islámico. Según Doutté (1909, p. 6), como consecuencia de esto, "el pueblo marroquí concibe actualmente la soberanía del sultán bajo la forma morabítica": "En tanto que jerife, el sultán posee baraka; él es el morabito principal del país. Su baraka, al igual que la de los morabitos, se transmite por contacto". Las palabras de Doutté nos conducen a una concepción panafricana de la monarquía y a las funciones organicistas y taumatúrgicas que les son atribuidas más allá del África islámica. En fin, Doutté siempre será sospechoso, por su carácter procolonial, de tener una concepción tradicional y conservadora de la monarquía alauita.

Édouard Michaux-Bellaire (1925, p. 145), otro relevante etnógrafo de la época colonial, cuenta de Marruecos y su relación con el califato:

Será difícil desenmarañar, en medio de todas las complicaciones de la historia de Marruecos, si es el principio de la soberanía el que ha creado el califato o, al contrario, si se ha establecido sobre el principio del califato. Parece que el califato ha sido siempre el fin ideal de aquellos que han ejercido la soberanía, que es así consagrado, por decirlo de algún modo, dándole el carácter religioso y la fuerza tradicional necesarias para gobernar un Estado que es él mismo una verdadera comunidad políticoreligiosa.

Por encima de todo se enfatiza que Marruecos, el país de los jerifes, siempre ha sido reluctante a someterse a poderes de otra naturaleza, como el de los otomanos, ni siquiera por vía del beyato o gobierno indirecto turco.

Sobre la estructuración interna del majzén se habla del almulk (الملـــ como la "casa del poder" o "casa real", un proyecto comunitario cuya garantía sería divina (Hammoudi, 1999). Las bases de su poder residirían en la solidaridad orgánica o 'asabiya y en la alianza o beyâa. Según Hammoudi (p. 130):

Dar al-mulk existe como una entidad permanente, distinta de los grupos a través de los cuales se producen las relaciones de sociabilidad, trabajo y 
vida religiosa. Al igual que otras formas de regulación política, su tarea es influir en estas interacciones sin enredarse en los marcos sociales en los que se desarrollan.

Además, añade que “afirma una razón comunal (islámica), que se aplica universalmente tanto a los gobernantes como a los gobernados". Sus funciones no estarían claramente definidas, sino distribuidas entre los campamentos provisionales o mehallas, con sus jerarquías militares y civiles, secretarios, servidores domésticos, etcétera, y los palacios reales, donde esta estructuración estaría más nítidamente delimitada (pp. 134-135). El servicio personal no se recompensaría con un salario claramente establecido, sino con regalos. Para finalizar, Hammoudi (p. 170) reflexiona sobre lo que significa hoy día al-mulk:

La nueva especificidad de Dar al-mulk consiste en la legitimación de una estructura autoritaria moderna. Se basa en el hecho de que ya no depende de formaciones locales (tribus, jefes, zawiya, etc.) que negocian su autonomía al mismo tiempo que apoyan a un centro más poderoso que se beneficia de un amplio consenso [...] La nueva especificidad de Dar al-mulk como campo de relaciones de poder consiste en la generalización de la práctica del servicio, del don y del terror sacralizado, no sólo a través del nuevo aparato tecnoburocrático, sino también a través de la estructura anticolonial y poscolonial de la movilización.

El aprendizaje del concepto de autoridad sería esencial. Se ha hablado así del vínculo maestro-discípulo como fundamento de las relaciones autoritarias de poder en el mundo marroquí (Hammoudi, 2007). Tenemos una fuente privilegiada, de primera mano, para estudiar el funcionamiento del majzén en la obra autobiográfica del príncipe Muley Hicham (2014). Éste relata cómo el majzén, incluso en los viajes al extranjero de Hassan II, cuando se trasladaba a otro país de cultura radicalmente distinta, conseguía hacer gravitar todo en torno a su concepto protocolario y de poder mediante eficaces mecanismos de seducción. Autoritarismo y seducción permiten restablecer la dialéctica del amo y del esclavo.

Físicamente, el majzén estaría radicado en una de las cinco ciudades catalogadas como "imperiales" del imperio jerifiano: Fez, Marrakech, Tetuán, Rabat y Mequínez. 


\section{El majzén en la época de los sultanes Abdelaziz, Hafid y Yussef: conspiración y segmentariedad}

El periodo que va de 1894 a 1927 en la historia contemporánea marroquí estuvo marcado por la inestabilidad política, lo que dio lugar al acceso al poder, sucesivamente, de tres hermanos, hijos del sultán Muley Hassan (1836-1894).

En primer lugar está el sultán Muley Abdelaziz (1881-1943), el cual había desplazado en la línea de herencia a su hermano primogénito Muley Mohammed a la muerte de su padre Muley Hassan, en una expedición o mehalla al oasis de Tafilalet. Obtuvo el poder gracias a las intrigas de su madre, la esclava circasiana favorita del sultán, Lalla Regia, mujer considerada muy hábil, y del hayid o secretario particular, Ben Ahmed (Martinière y Lacroix, 1894). La opinión sobre el mandato de $\mathrm{Mu}-$ ley Abdelaziz es cambiante entre sus coetáneos. La prevaleciente en las medinas era muy negativa por muchos y acumulados motivos que iban desde el rechazo popular al establecimiento de nuevos impuestos de influjo occidental, hasta el gusto desmedido que el sultán tenía por las diversiones modernistas, muchas de las cuales le eran proporcionadas por sus íntimos europeos, como el británico Harry MacLean, caíd en la guardia real, o el francés Gabriel Veyre, ingeniero de palacio, antiguo representante de los hermanos Lumière, que rivalizaban entre sí por ganarse su voluntad, aportándole las últimas novedades de sus respectivos países, fuese la fotografía, el cine, un globo aerostático o un tren. El cálculo de los franceses, señala un contemporáneo (Weisgerber, 1947, p. 163), se rompió cuando su país premió públicamente la fidelidad a los poderes europeos de Abdelaziz:

El gobierno francés le dio un golpe de gracia a su popularidad enviándole el gran cordón de la Legión de Honor, cuya imposición solemne fue explotada por sus enemigos como una representación del bautismo (cristiano) del Comendador de los Creyentes.

En cualquier caso, en fuentes coetáneas se describe que "el reinado de Muley Abdelaziz fue, a pesar de las hermosas dotes que adornan a éste, pródigo en intrigas y sublevaciones" (Los 
sultanes de Marruecos, ms.). El asunto ha quedado así fijado en la historiografía, incluso la marroquí más oficial (Kably, 2012). Y hoy día se pasa de puntillas sobre su figura.

El periodo de la sublevación de Muley Hafid (1873-1947) contra su hermano el sultán coincide con esas grandes turbulencias que precedieron a la proclamación del Protectorado francés. Los primeros pasos de Hafid como gobernante se dieron en Marrakech. Su poder como pachá estaba circunscrito a una ciudad cerrada para los europeos, sobre todo tras la muerte del doctor Émile Mauchamp, asesinado por una turba en marzo de 1907 en Marrakech por haber instalado una antena de telegrafía sin hilos en lo alto de su casa en la medina (Katz, 2006). El clima xenófobo estaba muy arraigado en la capital del sur, sometida además a las tensiones con los caídes del Atlas (Maxwell, 2004).

Cuando Hafid se sublevó contra su hermano, las únicas fuentes de información procedían de los rumores que llegaban a Casablanca, propalados por los autóctonos. El rumor más insistente era que "Muley Hafid acababa de revolverse contra su hermano" y que, habiendo sido "proclamado sultán por los grandes caídes del sur, había declarado la guerra santa” (Houel, 2014). Desde luego, esta proclamación la facilitaba el hecho de que el gran caíd de Marrakech, Si Madani el Glaoui, había resultado muy ofendido por el sultán Abdelaziz por haberlo hecho devolver cien mil reales de un préstamo. Se dice que "este incidente debió haber generado una gran animosidad entre el jefe de los Glaoua y el majzén de Muley Abdelaziz” (ElMezouari, 2016, p. 80). Los Glaoua, de hecho, verdaderos feudales que gozaban de la simpatía francesa para controlar el territorio tribal y, por ende, "segmentario" del Atlas, se apuntaron a la sublevación de Hafid contra su hermano. A pesar de este apoyo trascendental, Hafid se encontró con la oposición de algunos caídes de la montaña.

Los golpes de efecto y los cambios de fidelidades estaban al día según marchara la campaña, con los franceses como árbitros de la situación (Justinard, 2015, pp. 72-75). Uno de los principales obstáculos que había superado Muley Hafid en el propio Marrakech era la competencia de Ahmed El Hiba, que ejercía como sultán del Sous. Ahora, El Hiba era combatido por los 
franceses con apoyo de Hafid (Abdessalam, 2013). En definitiva, los historiadores actuales señalan que la

política de los grandes caídes, un pliegue esencial de la "política indígena" del Protectorado, ha sido, en ciertas regiones del país, un instrumento práctico de dominación de las tribus "disidentes", al mismo tiempo que una fuente de legitimación de la extensión de la ocupación que ha llegado casi simultáneamente con la reestructuración de majzén a nivel central y regional (Kably, 2012, p. 570).

Complejidades que tienen su explicación en el sistema segmentario tribal y en la afición de los franceses a la etnografía, que les proporcionaba útiles instrumentos de colonización (Rachik, 2012).

El argumento principal de Hafid contra su hermano rezaba: "Mi hermano [...] no ha cumplido con sus deberes de jefe de los creyentes. Ha contraído préstamos que no han servido para levantar el imperio sino para satisfacer sus placeres. Esto ha comprometido la independencia de nuestro país" (Houel, 2014, p. 6). Estas opiniones las recogió el periodista francés Christian Houel en plena batalla, cuando los franceses aún se empecinaban en apoyar a Abdelaziz. Al estar muy cerca de Hafid en el conflicto por la Chaouia, región cercana a la estratégica Casablanca, Houel se consideró en parte responsable de la subida al trono de Hafid. El caso es que los ulemas, chorfas y notables de Fez, que eran el factor determinante para subir al poder, no destituyeron a Abdelaziz más que bajo presión popular, según los informes franceses (Maroc affaires diplomatiques. Politique générale [1908]; Maroc affaires politiques. Politique générale [1909], 11 de agosto/30 de septiembre).

Por su fama de hombre docto en leyes y teología islámica, Muley Hafid tuvo el apoyo, durante su sublevación, de la cofradía Kittaniya, liderada por el carismático Mohamed ibn Jafar El Kittani, al haber sido éste prácticamente quien le abrió las puertas de Fez. El apoyo de El Kittani procedía del compromiso del nuevo sultán de liberar Marruecos de la presencia europea (Maroc affaires politiques. Politique générale [1909], 11 de agosto/30 de septiembre). El Kittani se pronunció contra Hafid cuando lo vio titubear y aceptar el dictado francés en los momentos previos a la firma del tratado protectoral. 
Muley Hafid ha sido presentado a la vez como una marioneta de las circunstancias, como un individuo sagaz, como un adepto a las drogas inestable emocionalmente, o como un sujeto culto y versado en teología islámica. Su retrato bascula según sean las fuentes. De Muley Hafid señala su coetáneo, el doctor Weisgerber (1947, p. 160), que, pareciéndose en lo físico a su padre, el recordado Hassan I, carecía sin embargo de sus cualidades morales: "Muy letrado, jurista y teólogo, comerciante y especulador tan hábil como desnudo de escrúpulos, no tenía ningún ideal". Leemos en una fuente actual que fue "un hombre sombrío y meditativo, animado por una fe ardiente e irreductible opuesta a toda injerencia extranjera", a la vez que "era también - cosa que muchos ignoran- un poeta sensible y delicado, en el corazón del cual ardía la llama de las tradiciones marroquíes". Lo que se destaca de su carácter, según casi todos los informes, es la tendencia ciclotímica a "pasar, sin transición, de la cólera al abatimiento" (Benoist-Méchin, 1994, p. 93). En ello hay acuerdo.

Hay un documento en los fondos de la Biblioteca Nacional de España sumamente interesante para reconstruir la personalidad de Muley Hafid, atribuido al propio exsultán (Hafid, mecan.). Desde luego, ya fuese Muley Hafid o un conocedor íntimo del sultán dimitido y su entorno quien lo haya dictado, las apreciaciones contenidas en él son jugosas.

Según el documento, se hizo con el poder con apoyo de Si Madani el Glaoui y de Sidi Aisa Ben Aomar Kaid, con el fin de controlar sus cabilas. A pesar de ello, decidió eliminarlos:

La sutilidad de su carácter le hizo ver desde el primer golpe de vista que si con la ayuda de ellos había conseguido ser Emir el Muminin, sin esa ayuda podría algún día dejar de serlo, por lo que decidió llamarlos a su lado bajo el pretexto de colmarlos de honores y así recompensar sus grandes servicios, pero en verdad con el solo fin de tenerlos a su lado y así anular la fuerza que representaban las extensas regiones gobernadas por dichos caídes y que, faltas de su cabeza gobernante, no harían en ningún caso el más pequeño intento de rebelión, con lo que consideraba tener en tranquilidad y bajo su mano casi la mitad de su imperio.

Hafid desconfiaba de los poderes de los fuertes caídes aliados y tramó su destrucción política. Para ello empleó, según el relator, "un medio harto ruin y bajo": 
Principió [según su perverso plan] a exigir grandes sumas de dinero a ambos ministros, que no conseguían apagar su insaciable sed de oro y que El Guelaui abonaba sin dificultad alguna, pero, al tener en su mano el gobierno de una parte del imperio, esquilmaba a las cabilas imponiéndoles una contribución triple de lo que exigía el sultán, dándole a éste cuanto le pedía y apropiándose del doble de lo que a su señor le entregaba. No podía hacer lo mismo Sid Aisa Ben Aomar, pues su puesto de ministro de Negocios extranjeros no le producía lo más mínimo y no gobernaba más que sobre su cabila, a la que tenía debilitada con las exacciones de que la hacía objeto para satisfacer la voracidad del sultán; inició y fomentó Muley Hafid rencillas y adversidades entre ambos ministros, púsose del lado del Guelaui, que era el más fuerte, favoreció la sublevación de un hijo de Sid Aisa que pretendía arrebatar la autoridad de su padre en la cabila, con lo que consiguió el sultán la caída del noble y prestigioso caíd de Abda, al que por fin destituyó del puesto de ministro de Negocios Extranjeros y del Bajato de su cabila.

Como se observa, los métodos de Hafid estaban al menos en armonía con la segmentariedad arriba aludida mediante la hábil manipulación del juego de alianzas y contraalianzas. La díada majzén/tribu enmarca el reinado del sultán Muley Hafid entre 1909 y 1912. Contribuía a ello, sobre todo, el sustrato "tribal", pero no sólo eso, ya que el majzén estaba habituado a este tipo de comportamientos conspirativos.

El Glaoui, que había impuesto su autoridad sobre la segmentariedad de las tribus del Atlas, se negó a caer en ese juego, lo que provocó la irritación de su irascible señor. Así estaban las cosas cuando Hafid, hombre hábil en las intrigas palatinas, pensó una nueva estratagema: inventó un supuesto viaje suyo a aplastar una sublevación en el Hauz, en el país yebalí:

Esta política consistió en hacer publicar oficialmente su viaje enviando cartas a los caídes de las tribus para que le reunieran recursos pecuniarios que sufragasen los gastos del viaje y sacar a relucir su material de campamento Apaz implantándolo en las afueras de la población, custodiado por una escasa pero brillante y lucida guardia de su Palacio (Hafid, mecan., pp. 4-6).

Al hacer este falso movimiento se procuró una buena recaudación entre sus súbditos. No obstante, la rebelión real continuó en marcha en el territorio de los Cherarda, hartos de ser despojados por El Glaoui para satisfacer la codicia de Hafid (mecan., p. 6). La rebelión comenzó el 25 de febrero: 
Inútil es decir que dicha proposición fue acogida con extrema alegría por las cabilas, pues halagábales el no pagar derecho o impuesto alguno y hasta sus mismos caídes [del sultán] abrazaron con entusiasmo el movimiento, pues habiendo sido muy mal tratados por Muley Hafid durante las últimas estancias en la corte cherifiana, no querían desperdiciar la ocasión que le presentaba una venganza a los malos tratamientos de que fueron objeto [los había encarcelado y luego liberado a cambio de dinero] (Hafid, mecan., p. 7).

La división tribal operó a favor de Hafid, que siguió aplicando la política de "divide y vencerás" con las tribus, incluso con las tradicionalmente aliadas al majzén:

El odio inextinguible que desde hacía tiempo existía entre las cabilas de Hayaua y Ulad de Aisa, hizo que esta última, aun adicta al majzén, aprovechara la ocasión del levantamiento de su rival para satisfacer así sus deseos de venganza, sin que ésta fuese recriminada por el majzén en su día, pretextando haber atacado a una cabila levantada contra la autoridad del sultán, a la que saqueó e incendió por completo llevándose gran número de ganado, con lo que satisfizo su venganza y antiguos odios, verdadero objeto que perseguía, y haciendo a la par un alarde de adhesión al emperador que tendría su recompensa.

La “inestabilidad" era una norma sociopolítica segmentarista que ahora estaba incluso más acentuada por la intervención francesa, que buscaba paradójicamente acabar con la "anarquía” (Tharaud, 1920). Hafid, como había ocurrido en Marrakech, veía con agrado indisimulado la eficacia de la misión militar gala, que, por tenerla a su favor, le permitía obtener una superioridad militar sobre la disidencia (Hafid, mecan., p. 9). Así se explica que Hafid no haya puesto ninguna objeción al nuevo reglamento militar impuesto por los franceses y que limitaba las rapiñas de sus tropas, ya que en el fondo reforzaba su autoridad. Incluso lo veía con entusiasmo, aunque los caídes estuviesen totalmente en contra (pp. 10 y 67). Hubo conatos de sublevación en contra del reglamento. Lo cierto es que los franceses ayudaron a la causa de Hafid, pero la alarma por la ocupación militar en ciernes continuaba entre la población de las medinas (p. 68). El rumor en ésta sobre el secuestro de la voluntad de los sultanes por los franceses obró como factor de agitación permanente de Muley Abdelaziz a Muley Hafid. 
Un episodio requiere nuestra atención, pues forma parte de las intrigas palatinas y desvela el carácter de Hafid. Se trata del rumor que corría por la medina de que maltrataba a su hermano, Muley Mohamed, el heredero legítimo frente a Muley Abdelaziz y él mismo. Sospechaba Hafid de la connivencia de Mohamed con las harkas que rodeaban Fez:

La viva contrariedad que esto le producía, unida a la confirmación del aumento habido en la harka rebelde, dio ocasión a que se desarrollaran en Palacio violentas escenas entre el propio sultán y su prisionero hermano Muley Mohamed, llegando el primero en un momento de ira a intentar matar a su hermano por suponerle cómplice en los actuales acontecimientos, pero que la oportuna presencia del gran visir El Guelaui evitó que llevara a cabo el fratricidio. Persistente Muley Hafid en las suposiciones de hallarse Muley Mohamed en comunicación con los revoltosos, duplicó con él su vigilancia y tomó extremadas medidas de seguridad cargándole de pesadas cadenas (Hafid, mecan., p. 72).

Temía fundadamente Hafid que se utilizara el nombre de su hermano prisionero, como antes lo había hecho el líder rifeño El Rogui BuHamara al hacerse pasar por él con el fin de hacer un cambio de sultán (González Alcantud, 2014).

Muley Hafid, al comprobar que tenía muy poca capacidad de maniobra, lo que lo obligaba a firmar el tratado de Protectorado, a pesar de su discurso xenófobo y antieuropeo inicial, incitó a un levantamiento en la medina que estalló instigado por agentes del majzén un mes después de la firma del tratado protectoral con Francia y desató una ola de xenofobia contra franceses, civiles y militares, pero sobre todo se materializó con el asalto al mellah hebreo, al considerarse que los judíos eran colaboracionistas del nuevo estado de cosas. En este levantamiento murieron casi ochenta franceses y hebreos, muchos de ellos víctimas de un ensañamiento terrible. Lyautey fue el encargado de aplastar la revuelta, pero lo hizo procurando pactar con el majzén con el fin de evitar futuras sublevaciones (González Alcantud, 2010).

Estas circunstancias quizá provocaron en Hafid una marcada tendencia a la crueldad y a vengarse de aquellos que le recordaban sus debilidades. Los cónsules europeos protestaron vivamente por las crueldades que a diario transmitía la prensa metropolitana, con gran escándalo de la opinión pública (Maroc 
affaires politiques. Politique générale [1909], 11 de agosto/30 de septiembre). El caso más llamativo fue el fin de El Rogui, escenificado para infundir pavor entre sus contrarios, pero también el de El Kittani, antiguo aliado suyo que le recordaba con frecuencia sus compromisos (Bazzaz, 2010; González Alcantud, 2013b).

Francia, y sobre todo el general Lyautey, hábil colonizador, rehuyó desde el principio la colonización asimilacionista, doctrina oficial francesa, y optó por el Indirect rule británico, que consistía en un pacto con las élites indígenas. Para gobernar de manera indirecta, procuró tener controlados los movimientos políticos de los dos exsultanes marroquíes en el exilio, Abdelaziz y Hafid, amén de los del nuevo sultán, Muley Yussef. Acertaba Lyautey al considerar en el crepúsculo de sus días que la estabilidad de los alauitas en el poder había sido una creación suya: eran sus "criaturas". Para lograr sus objetivos tuvo hábiles colaboradores, como Sidi Kaddour ibn Ghabrit, un argelino de nacimiento, de Tremecén, cerca de la frontera marroquí.

Ghabrit había estudiado en la principal mezquita de Argel, y luego en la Qaraouyín de Fez. Había sido drogmán en la legación francesa de Tánger, donde aprendió el oficio de intermediar. Estuvo cerca del sultán Muley Hafid en los momentos de la firma del tratado de 1912 y, al parecer, fue una figura clave en la sombra en la conclusión de este acuerdo, al hacerle saber a Hafid que necesitaba el apoyo francés para combatir la inminente sublevación de las tribus (Theline, 2010). Ghabrit fue pagado por el majzén y por Francia con el puesto ad hoc de "jefe de protocolo" en París (Ottmani, 2010).

Las relaciones de Muley Hafid con Ghabrit, como verdadero representante y jefe de protocolo del majzén en París, también eran buenas. Ghabrit le sirvió de intermediario en numerosas ocasiones. Esa buena relación se proyectó en el tiempo (Maroc. Le sultan et les personnages marocains, 1917-1927). En definitiva, el argelino jugaba en la corte majzeniana el mismo papel que en su momento ejercieron MacLean y Veyre en la corte de Abdelaziz. 


\section{El exilio de Muley Hafid en España y Francia, episodio "segmentario" en las relaciones hispano-francesas}

Muley Abdelaziz había gozado desde siempre de las simpatías galas, que sólo declinaron al final por una cuestión puramente instrumental, por ello sus bienes y sus necesidades estuvieron cubiertos por Francia en su exilio. La metrópoli le pasaba en concepto de pensión seis mil francos mensuales para sufragar sus gastos en tierras francesas (Maroc. Le sultan et les personnages [corrigé "personnalités"] marocains, les anciens sultans Moulay Abde el Aziz, 1917-1937). Le facilitaron igualmente las transacciones con sus propiedades en Marruecos, sobre todo las ventas. Gracias a que los servicios secretos galos lo vigilaban estrechamente, tenemos gran cantidad de material desclasificado que informa de sus pasos. Por ejemplo, cuando en enero de 1918 estuvo en Niza, amén de visitarlo un general francés, recibió la prensa en árabe, fue a los espectáculos en teatros de Niza y Montecarlo y también atendió a un miembro de la cofradía sufí colaboracionista Tijjaniya (Maroc. Le sultan et les personnages [corrigé “personnalités”] marocains, les anciens sultans Moulay Abde el Aziz, 1917-1937).

En mayo comenzaron las alarmas por los gastos del exsultán, que se encontraba de viaje continuamente. El relator sostiene que la pensión había sido prevista para que permaneciese estable en su residencia de Burdeos, pero que los excesos viajeros habían desbordado los costos. El general Lyautey, su supervisor, decidió un mes después aumentarle la asignación. El control sobre el exsultán era tan estrecho que, a veces, llegaba al ridículo: "La vigilancia ha tenido que ser abandonada en la Puerta de Boulogne a consecuencia de la avería del motor del vehículo ocupado por los inspectores", dice el informe secreto. En el ínterin, el Senado se negó a subirle la asignación propuesta por Lyautey e incluso se planteó suprimirle el coche con el que frecuentaba "todo París". Abdelaziz protestó y, por si estas medidas tenían que ver con alguna situación en Marruecos, aseguró que no tenía nada en común con algunos agitadores que habían evocado su nombre.

Se vigilaba en especial el estado de ánimo de Abdelaziz, derivado tanto de asuntos personales, como la muerte de su influ- 
yente madre Lalla Regia, como públicos, como el curso de la guerra mundial. Para evitar que tuviera una mala opinión de la situación de Francia, se pensó en trasladarlo a Vichy. Como se intentaba vender unos terrenos de propiedad disputada, se consideró la posibilidad de que el exsultán hiciera un viaje a Tánger. Lyautey tenía claro el peligro potencial que constituía Abdelaziz si volvía a Marruecos, ya que su prestigio estaba "intacto, sobre todo entre los bereberes de la montaña".

Al contrario de Muley Abdelaziz, Muley Hafid tuvo siempre el apoyo soterrado alemán, lo que le ganó la animadversión gala. Los franceses lo habían apoyado inicialmente, aunque con algún titubeo, frente a su desacreditado hermano Abdelaziz. Piénsese que Alemania, desde finales del siglo XIX, tenía gran influencia comercial sobre el reino jerifiano, a la cual sólo puso freno parcialmente la Conferencia de Algeciras de 1906, cuando participaron los delegados enviados por Abdelaziz, que se vieron obligados a optar por la entente franco-británica con el apoyo español y estadounidense (González Alcantud y Martín Corrales, 2007). Los franceses siempre sospecharon que Hafid quería torcer la voluntad internacional surgida del acuerdo de 1906.

Desde luego, la Primera Guerra Mundial puso a prueba el vínculo metrópoli-Protectorado. La consigna de la época parece haber surtido efecto, ya que Francia pidió a Marruecos "darle soldados, obreros y cereales" (Résidence générale de la république française au Maroc, enero de 1918). Las rebeliones internas se asociaban en buena medida a las intrigas alemanas para ganar terreno e influencia en Marruecos. Se ve su mano tras el caso de Raisuni, el señor de Yebala, que jugaba a varias bandas, pero en el que siempre prevaleció su germanofilia (Forbes, 2010).

En los acontecimientos de la elección de un caíd con motivo del moussen de Moulay Abdessalam, por ejemplo, arguyen los servicios franceses: "Esta elección está dirigida por los alemanes y netamente orientada contra nosotros. El cónsul de Alemania en Tetuán, el exagente de los correos alemanes en Tánger, Bohn, se relaciona con todos los notables de los alrededores" (Résidence générale de la république française au Maroc, febrero de 1918). Se tiene constancia, por otra parte, 
de que varios disidentes del área de Marrakech habían recibido cartas y subsidios del sultán otomano, e incluso que se esperaba la llegada de dos submarinos alemanes que ayudarían al Hiba en su insurrección del sur (Résidence générale de la république française au Maroc, febrero de 1918). En marzo, los franceses estaban pendientes de las inclinaciones proalemanas y proespañolas de Raisuni: los españoles sabían que el líder yebalí había pedido la protección alemana para su hijo mayor y que estaban predicando la "paz santa" con el fin de reunir a las tribus de su entorno. Los agentes alemanes circulaban libremente por el territorio de Raisuni (Résidence générale de la république française au Maroc, marzo de 1918).

Raisuni pretendía que los españoles lo nombraran gran visir de su zona protectoral, pero éstos no se hacían mucha ilusión con su lealtad. Mientras tanto, en abril de 1918, se informó que se estaban desembarcando armas alemanas para los gomara y otras tribus sometidas a Raisuni (Résidence générale de la république française au Maroc, abril de 1918). En mayo, Raisuni siguió con la idea de convertirse en gran visir.

La acción alemana sobre Marruecos preocupaba tanto que incluso se elaboró un mapa de las zonas de influencia germana en el mes de junio. En dicho mapa se observa que los campos de acción de los alemanes serían Yebala, con Raisuni al frente, el Rif, con Abdelamlek de jefe reconocido, y las zonas del medio y alto Atlas, y el Draa (Résidence générale de la république française au Maroc, junio de 1918). En definitiva, zonas de $s i$ $b a$, o segmenteriedad tribal tradicionales.

En julio, Raisuni decidió alejarse de los españoles, y con ello recuperó prestigio entre los suyos. "De repente, las conversaciones que iban a terminar con el nombramiento de Raisuni como gran visir, han sido interrumpidas. Serán verosímilmente retomadas. La prensa española constata que es difícil, al punto donde las cosas han sido llevadas desde hace dos años, para pasar del cherif" (Résidence générale de la république française au Maroc, mayo de 1918). Los alemanes, según los informes franceses, no renunciaban a hacer de la zona española una colonia alemana. Empleaban instrumentos como la germanófila Compañía Española de Colonización, que pactaba con Raisuni a cambio de armas y subsidios (Résidence générale de la 
république française au Maroc, julio de 1918). El consulado de Austria en Larache se convirtió en centro de agitación y propaganda antifrancesa.

En noviembre de 1918, se sabe que los alemanes merodeaban por Larache en la búsqueda de un acuerdo con la cofradía Derqaoua (Maroc. Le sultan et les personnages [corrigé "personnalités"] marocains, les anciens sultans Moulay Abde el Aziz, 1917-1937). Nos encontramos ante un mundo de pura intriga que aprovechaba en su favor los movimientos de la segmentariedad, al menos por su concepción de las alianzas y las contraalianzas.

Hagamos un alto para analizar el curso de la guerra y el impacto que tenía en el Protectorado. Había en Francia gran preocupación por los efectos del conflicto en la opinión pública española, en la de la zona de ocupación, y en la árabe en general. Lyautey, que abandonó Marruecos para hacerse cargo del Ministerio de Defensa en plena Guerra Mundial, estaba en contacto con el ministro de Asuntos Exteriores francés y la agencia Havas para encauzar la contrainformación (Information-Presse..., 1914-1940, vols. 49 y 45ca-52). El cónsul honorario de Tetuán señaló que los comunicados alemanes en lo tocante a Marruecos llegaban el mismo día y eran reproducidos en el diario local El Eco de Tetuán. Pidió recibir cada día por telégrafo las noticias de Havas para transmitirlas al mismo periódico, que las publicaría:

Me tomo la libertad de insistir en la importancia que presenta para Tetuán (donde se encuentran los servicios civiles y militares de la Residencia General española, e igualmente una guarnición de cerca de 20000 hombres), la publicación cotidiana de nuestros comunicados oficiales transmitidos telegráficamente.

La guerra psicológica en el Protectorado conllevaba el control de la opinión pública y, por ende, el de los servicios de telegrafía que transmitían las noticias de prensa. Todo tenía, además, repercusiones en España, oficialmente neutral en el conflicto europeo. Se dieron continuas interferencias en España del servicio diplomático francés para contrarrestar la propaganda telegráfica alemana reproducida en los periódicos tanto de Madrid como de provincias (Information-Presse..., 
1914-1940, vol. 17). Lyautey desempeñaba un papel clave en el control de la información.

En enero de 1919, Lyautey seguía creyendo que era muy prematuro pensar en la vuelta de Abdelaziz a Marruecos a pesar de su probada fidelidad. Terminada la guerra, el exsultán no comprendía por qué, tras el fin del conflicto europeo, era retenido en Francia. No obstante, en medios diplomáticos se pensaba que Abdelaziz debía ir a Marruecos y ser exhibido como un triunfo de la política francesa. En julio del mismo año Lyautey, al fin, consideró que podría ser "útil” la presencia del antiguo sultán en Tánger, ya que ayudaría a pacificar algunas intrigas locales (Maroc. Le sultan et les personnages [corrigé "personnalités"] marocains, les anciens sultans Moulay Abde el Aziz, 1917-1937). Se preparó la vuelta de Sidna Muley Abdelaziz a Tánger. Se pretendía que, si vivía temporalmente ahí, una ciudad diplomática y no imperial, se evitaría la reivindicación de su figura. En la audiencia que el presidente Berthelot le concedió antes de su vuelta, Abdelaziz protestó por su larga e injustificada estancia en Francia.

En el viaje de vuelta pasó por España, pues había prometido al rey español hacerle una visita. Se detuvo en Santander, lugar en que se encontraba Alfonso XII, y temió toparse con su hermano Hafid, que vivía allí, en su aún inacabado exilio español. Llegó a Tánger de incógnito, y sólo al día siguiente se enteró la población. En la primera audiencia habló con El Menebhy, su antiguo ministro de Guerra. A partir de ese viaje, las visitas a Tánger se hicieron más frecuentes en los siguientes años. Su tren de vida obligó una vez más a Lyautey a subirle la pensión, aunque él mismo había adquirido liquidez vendiendo algunas de sus propiedades tangerinas a compradores ingleses y norteamericanos. Los disidentes de la zona española soñaban con hacerle desempeñar un papel reivindicativo aún en agosto de 1921. Su vida en Tánger, por el contrario, consistía en jugar su deporte favorito, el golf, y no se inmiscuía en intrigas locales. En noviembre de 1922, el reinante sultán Muley Yussef lo invitó como señal evidente del clima relajado entre ambos, y de los escasos deseos de intrigar del antiguo sultán. No fue sino hasta 1937 cuando, tras un viaje a la zona francesa, los nacionalistas volvieron a reivindicar su figura. Murió sin pena 
ni gloria en Tánger en 1943, refugiado en sus divertimentos y sin haber intervenido en la política interior marroquí.

Muy distinto es el caso su hermano, el sultán Muley Hafid. Como se dijo, era un hombre muy controvertido que, a pesar de haber sido apoyado en el último momento por los franceses, carecía, sin embargo, de su confianza. Sobre todo tras las llamadas “journées sanglantes" del 12 al 17 de abril de 1912. Muley Hafid cedió en 1912, forzadamente, como consecuencia de este pogromo antifrancés y antihebreo, el poder a su hermano Yussef. Este último fue, como señalamos, un instrumento en manos del verdadero dueño de la situación, el experimentado militar colonial Hubert Lyautey.

Una vez depuesto Hafid, se refugió primero en Rabat y luego en Tánger, destino final de los derrocados. El hostigamiento de Lyautey al poner en cuarentena sus bienes, lo llevó a abandonar Marruecos en dirección a España. Hafid no confiaba en los franceses que ya tenían en sus manos a Abdelaziz. El caso es que Hafid, como consecuencia de las sospechas y la desconfianza que levantaba en la administración francesa, prefirió sin titubeos exiliarse en España. Los franceses no temían de las intenciones españolas, pero sí de las maniobras que pudiese hacer Hafid con los alemanes, eternamente resentidos con las consecuencias de la conferencia de Algeciras de 1906.

Los franceses se volvieron cada vez más duros con Hafid, conocedores de sus maniobras progermanas tanto en sus días de gloria, cuando estaba en el trono, como ahora, en el exilio (Maroc affaires politiques. Politique générale [1909], 11 de agosto/30 de septiembre). Los servicios de espionaje franceses conocían la correspondencia entre el príncipe Ratibor, embajador de Alemania en España, y Hafid, y convirtieron esta relación en la principal pieza de la acusación contra su persona. Incluso había un rumor insistente de que los alemanes iban a evacuarlo en un submarino que enviarían hasta Melilla, desde donde penetraría en Marruecos, ayudado por españoles germanófilos. De hecho, en una misiva firmada en Barcelona el 1 de julio de 1916, Hafid preguntó al embajador alemán si era posible su vuelta a Marruecos en el submarino U-35. En otra del 24 de agosto afirmó que en diferentes cabilas esperaban su vuelta. Con ello se confirman las sospechas francesas. Añadió que los 
"maures" que habían llegado a Barcelona para parlamentar con él habían sido expulsados por la policía española y que él mismo se encontraba bajo vigilancia. Esgrimió dolido los insultos que recibía de España e insistió en que era necesaria su presencia en Marruecos. En una carta firmada en El Escorial el 19 de enero de 1917, informó que daba "un modesto óbolo" para la suscripción de víctimas de guerra abierta por la embajada alemana, amén de hacer profesión de una "amistad absoluta y una admiración entusiasta por el gran soberano" germano.

En marzo de 1917, los informes confidenciales franceses señalaban que Hafid movía con dinero del imperio los hilos desde El Escorial para apoyar un levantamiento de las tribus, coordinado con Raisuni, el "sultán de las montañas" yebalíes, también proalemán, como vimos. Por ello, se recomendó tener estrechamente vigilado a Hafid para evitar que escapara y se uniera a los sublevados. Pocos días después recibió la advertencia del barón Von Stohrer sobre ciertos sujetos marroquíes, cercanos a él, contrarios a la causa alemana. El 7 de abril manifestó su adhesión explícita a ésta después de que Estados Unidos entrase oficialmente en guerra con Alemania. En agosto de 1917, detectaron los franceses que Hafid había dado órdenes de hacer la guerra santa a un comerciante de Marsella. Finalmente, como culminación de esta entrega de Hafid a la causa alemana, en octubre felicitó al emperador por sus victorias en Venecia y Riga.

Los alemanes no fueron los únicos que apoyaban al antiguo sultán en sus intrigas, los turcos lo hicieron igualmente. En julio de 1918, Hafid anunció que se iba a Galicia, para cuyo viaje pidió a la embajada turca su asignación trimestral. Asimismo, se le informó desde Estambul que el "emperador" había acordado darle treinta mil pesetas mensuales. Se le localizó en febrero de 1918 en Barcelona, intrigando para organizar un levantamiento apoyado por un turco llamado Kismet, respaldado con dinero alemán.

Los padecimientos económicos de Muley Hafiz derivaban de su tendencia al despilfarro sin tener recursos de reposición, dado que España no era generosa en este dominio, bien porque no tenía conciencia de la importancia del juego político del exsultán, bien por temor a la ira de los franceses, deriva- 
da de un probable incumplimiento de los acuerdos diplomáticos de 1906 y 1912.

La imposibilidad de vender el palacio tangerino por el embargo decretado por Lyautey afectó mucho económicamente a Hafid. Las cosas de valor, libros manuscritos, los había sacado de Marruecos y los había llevado consigo a España, aunque los franceses sospechaban que algunos pudieran haber ido a parar a manos de editores egipcios. De hecho, los agentes de Lyautey localizaron en El Cairo uno de esos manuscritos y exigieron su devolución. Hafid dirigió una irritada carta al cónsul francés en Tánger sobre la posesión de los libros, algunos de los cuales, esgrimió, él mismo había hecho imprimir en Fez, en dos tipografías que había adquirido para este fin. Atacó personalmente a Lyautey, su mayor enemigo, del cual dijo que no pretendía más que alzarse con los laureles. Los términos de su carta son duros y exigentes. El talón de Aquiles para Hafid era su debilidad económica, y con ello contaba Francia.

Durante sus idas y venidas por España en su exilio, el antiguo sultán se movió preferentemente por Madrid y, por temporadas, por San Sebastián, Barcelona y Málaga. El espionaje español le marcó los pasos, sobre todo cuando viajó acompañado por diputados o personalidades españolas. El militar José Millán Astray, fundador de la Legión Española o Tercio de Extranjeros, escribió sobre Hafid e informó que era un hombre cultivado, incluso poeta, que vestía a la europea tocado con el fez tradicional, que mezclaba en su trato social una reserva de intimidad, aunque estaba deseoso de ejercer la munificencia haciendo regalos, sobre todo relojes, y que incluso había regalado un elefante al zoológico de Barcelona. Su popularidad en esta ciudad era mostrada a través de la música que había compuesto el maestro Vives para él (Millán, 1918). Figura popular, pues, este sultán arruinado que buscaba el plauso y el cariño públicos.

Empero, los franceses no renunciaban a conseguir que se instalara de buen o mal grado en territorio galo, para tenerlo bien controlado. En 1918, Lyautey había ordenado el secuestro de los bienes marroquíes de Hafid con el fin de presionarlo a que se entregara a Francia. Debido a sus innegables padecimientos económicos, Hafid se prestó a negociar en noviembre de 1918, 
en plena guerra europea, con un enviado francés, un tal Dr. Many, "judío francés", que actuaba de administrador de sus bienes incautados en Tánger. Este judío turco era protegido español, si bien había hecho su carrera en Francia y estaba en buenas relaciones con el consulado francés. Many le transmitió que debía fijar su residencia en Francia.

El gobierno español era a esas alturas partidario de una “oportuna” reconciliación de Hafid con Francia. En el otoño de 1918, Hafid percibió la hostilidad del afrancesado gobierno del conde de Romanones y estaba consciente de que éste consideraba expulsarlo de España. El gobernador de Barcelona le comunicó fríamente que su gobierno lo condenaba "caballerosamente al suicidio", y él hacía declaraciones a la prensa en que manifestaba abiertamente su desesperación y esgrimía que había abdicado porque no quería vivir bajo el yugo francés (Una conversación con Muley Hafid, 15 de febrero de 1920).

Romanones le propuso, como salida, su reconciliación con Francia. A pesar de las subvenciones alemanas y turcas, los apuros económicos de Hafid se siguieron incrementando. Cuando en la primavera de 1919 se produjo la visita de la cuñada de Romanones a Tánger, se sospechó que su viaje tenía que ver con la compra del palacio de Hafid. Por ello, Francia advirtió oportunamente a España que los bienes del antiguo sultán eran inalienables. En septiembre de 1919, Hafid estaba en San Sebastián, donde gozaba de los créditos de la casa Figueroa, probablemente avalados por sus bienes marroquíes. Romanones estaba muy obsequioso con Hafid y volvió a la carga con el tema de que se reconciliara con Francia. Incluso le sugirió que marchara antes a Bélgica. No obstante, aunque los españoles sabían que las intrigas de Hafid durante la guerra en Marruecos sólo habían servido para enervar a Lyautey, tenían en consideración los intentos, a petición del rey español, del antiguo sultán para solventar el conflicto con el líder rifeño Abdelkrim.

Pero los padecimientos de Hafid continuaron: en agosto de 1919 volvió a San Sebastián, donde vivía de la venta de sus joyas en Lausana y París. El dinero alemán escaseaba o ya ni siquiera llegaba. Desesperado, Hafid intentó el chantaje: sostuvo que tenía documentos comprometedores y que los destrui- 
ría si no se le pagaba la mensualidad prometida. Pidió ayuda a Inglaterra y a Egipto para solucionar su situación. Corrieron rumores sobre la miseria en que vivían sus hijos en Tánger. El 5 de noviembre de 1921, el sultán Muley Yusef, instigado por Lyautey, firmó un dabir que confiscaba definitivamente los bienes de su hermano Hafid. A partir de ese momento, irritado, comenzó a dirigirse a los franceses en español para hacer evidente su enfado. También se produjo la intermediación del jerife de la cofradía Tijjaniya, quien intentó demostrar que Hafid siempre había sido favorable a Francia.

En medio de esta tensión se produjo una entrevista con un enviado galo. La finalidad, en teoría, era calmar al antiguo sultán (Maroc. Le sultan et les personnages marocains, 1917-1927). Durante la entrevista, Muley Hafid se encontraba acompañado de su secretario, de un criado negro y de un español de su confianza llamado Contreras. Hafid se dirigió con agresividad al enviado francés. Le echó en cara a Francia que lo había obligado a abdicar a cambio de una pensión que no habían respetado. El interlocutor le contestó que había dimitido por voluntad propia, ya que tanto Lyautey como Regnault querían que continuase en el poder. Contestó Hafid que le habían ofrecido dos millones y medio de francos por la abdicación. El francés lo corrigió afirmando que se la habían retirado cuando huyó a España. La misma razón tenía el secuestro de sus propiedades. Luego discutieron sobre el abandono de su familia en Tánger, y cómo el sultán reinante, Yussef, se había visto obligado a tomarla bajo su protección. La familia de Hafid se cuantificaba en alrededor de 200 personas. El enviado francés esgrimió la vida “opulenta” que llevaba, y en concreto le echó en cara haber comprado 65 fusiles para distribuirlos entre sus compañeros de caza sin reparar en gastos. Los ingresos que había obtenido con la práctica del tiro de pichón luego los habría perdido en la ruleta. Estaba claro que Hafid no quería volverse un prisionero "de Estado" como su hermano Muley Mohammed lo había sido de su otro hermano, Abdelaziz, y de él mismo, y por eso manifestó que quería ir a un país musulmán, a El Cairo, a La Meca o a Bagdad (Maroc. Le sultan et les personnages marocains, les anciens sultans Moulay Abde el Hafid, 1917-1920). Los franceses, sin embargo, objetaron que 
su presencia en esas ciudades árabes crearía expectativas nacionalistas entre la población. Sólo considerarían acaso que se estableciese en las afueras de Túnez.

El interlocutor francés señaló que era imposible "hacerlo entrar en razón”. Al cabo, cedió y aceptó escribir una carta al presidente de la República francesa en la que, para salir del atolladero, habla de un "malentendido" entre él y Francia. Al final de la entrevista, Hafid pidió un gesto de generosidad a la metrópoli y le solicitó a Francia que asumiera sus deudas españolas, que ascendían a ochocientos mil francos, ya que, adujo, los españoles no querían dejarlo marchar mientras no las saldara.

Francia no aflojó la presión sobre Hafid, quien contempló la posibilidad de vender sus bienes en Marruecos a un grupo de capitalistas franceses. El Glaoui estaba por medio, y el compromiso del antiguo rey era dejar el dinero en Francia. También exigió que se pagaran los estudios y la manutención de sus hijos, que se encontraban en el palacio de Rabat. Pensó que no se les podía dejar sin recursos, ya que, al ser de linaje chorfa, esto crearía una situación sin precedentes y generaría mucho malestar entre los marroquíes.

Para llevar a término la operación de venta era necesario levantar el secuestro de sus bienes (Maroc. Le sultan et les personnages [corrigé "personnalités"] marocains, les anciens sultans. Moulay Abde el Hafid, mayo de 1921-abril de 1922). Con ese fin, se exigió previamente a Hafid la sumisión completa a Francia. El 8 de julio de 1921, a mediodía, se presentó Hafid en la embajada francesa en Madrid, donde hizo una declaración de sumisión a la metrópoli y mostró su abatimiento por el alejamiento de su familia y el hecho particular de haber perdido últimamente a tres de sus hijos. Juró por su honor y su religión mantenerse fiel a Francia, pero el embajador, en nota confidencial anexa, dijo no poder confirmar la sinceridad de sus palabras.

A pesar de todo, Hafid, en mayo de 1922, continuó protestando ante el gobierno de Poincaré. Incluso elevó una protesta ante la Ligue Française pour la Défense des Droits de l'Homme et du Citoyen contra el decreto de expropiación de sus bienes en Marruecos (Maroc. Le sultan et les personnalités marocains. 
Les anciens sultans, marzo de 1922-diciembre de 1924). Como siguió manifestando su deseo de irse a Egipto, el británico Balfour se puso en contacto con Poincaré para evaluar esa posibilidad. Lyautey puso en guardia a Balfour sobre el carácter intrigante de Hafid. Las deudas de Hafid en Madrid continuaron acumulándose y los deudores amenazaron con llevarlo a los tribunales. El exsultán amenazó con suicidarse ante las reclamaciones de los deudores. Por la gravedad de la amenaza, la embajada francesa asumió sus deudas. Lyautey ordenó liberar setenta mil francos para pagarlas. La condición francesa fue que aceptara vivir en Francia. Ibn Ghabrit y el coronel Huot fueron los encargados de arreglar los asuntos de Hafid en París para facilitar su traslado.

Hafid siguió teniendo, no obstante, un miedo cerval a entrar a Francia, donde pensó que lo someterían a las peores torturas hasta asesinarlo. Cuando todo parecía marchar para que viajara a París, decidió en el último momento permanecer en Madrid "para solucionar sus cosas". Al final fue autorizado a entrar a Bélgica tras una nueva conversación con el enviado de Lyautey. Como deseo último, pidió ir a pasar una jornada en Granada, ya que quería visitar sus monumentos árabes antes de abandonar definitivamente España. Varias veces insistió en que, en Francia, deseaba ser tratado no como particular sino como un antiguo soberano. Los franceses querían que fuera a París y que luego se estableciera en Niza o en sus alrededores. Continuó poniendo obstáculos pueriles para entrar a Francia y prolongó sus negociaciones sobre el destino de sus bienes marroquíes. La negociación parecía interminable.

La estadía española de Hafid fue expuesta sintéticamente por los escritores Jean y Jérôme Tharaud, muy vinculados al general Lyautey, en una entrevista en la que hablaron de que, aunque su sultanato no había durado más que cinco o seis años, había dejado en Marruecos "un recuerdo imborrable" por haber concurrido en su mandato muchos hechos "históricos". Telefonearon al antiguamente arrogante sultán, que, contra todo pronóstico, los recibió de inmediato.

Los Tharaud acudieron expectantes a entrevistar a un sujeto que les producía a la par admiración y terror: "Entre los pacíficos burgueses ha dejado el recuerdo de un chitân, es de- 
cir, de un diablo", dijeron los Tharaud (1925, pp. 62-73), y señalaron que durante el tiempo que había permanecido en España lo había hecho "fastuosamente en Madrid, bastante bien acogido por el rey y la sociedad española”. La salida de España de este polémico y temido monarca en desgracia, que se había aferrado a no caer en manos de los franceses, que seguían considerándolo el responsable último, con su carácter conspirativo, de las jornadas sangrientas de abril de 1912 en Fez, tuvo algo de opereta. Los Tharaud señalaron el miedo del sultán depuesto al paso de túneles en el tren.

Desde luego, ninguna de las intrigas de Muley Hafid en España estaba desprovista de interés para los propios españoles. A criterio de Francia, los españoles habrían conocido una gran prosperidad derivada de su neutralidad en la guerra mundial, la cual habría desarrollado "una suerte de nacionalismo que no podía casi ejercerse más que sobre la cuestión marroquí”. En el fondo, estaba la cuestión de Tánger: "La idea de que Tánger debería ser de España se ha insinuado desde hace algunos meses en los espíritus como la consecuencia natural del alza anormal del cambio y de las exportaciones" (Résidence générale de la république française au Maroc, Maroc espagnol et Tanger). Los deseos españoles de hacer política en Marruecos se habían disparado, frente a los acuerdos poco satisfactorios de 1906 y la subordinación al dictado francés, bajo cuyo mando estaba el majzén, derivado del tratado de 1912, aprovechando la debilidad francesa por su implicación en la guerra mundial.

Por otro lado, el sultán de hecho y por derecho, Muley Yussef, cuyo mandato fue de 1912 a 1927, en coincidencia con el esplendor de la era lyauteyana, fue un hombre de circunstancias, sostenido por Lyautey como su "criatura". El residente general operaba como verdadero "magicien" del teatro del poder: cuando se encontraba en público con el sultán Yussef, hacía ostentación de ser su subordinado. Al fin y al cabo, era un monárquico convencido, y esta subordinación le salía natural (Rivet, 1988; Teyssier, 2004). Enfatizó y engrandeció los rituales públicos del sultán:

Su Majestad - escribió de una entrada en Rabat- ha entrado solemnemente en la ciudad precedido de la guardia jerifiana y escoltado por los 
notables y la caballería de las tribus, tropas de la guarnición formaban la haie, gran afluencia de población se situaba en el paso del cortejo y aclamaba a Muley Yussef, que se mostraba particularmente sensible a los sentimientos manifestados por su pueblo (Maroc. Le sultan et les personnages marocains, 1917-1927).

Lyautey conocía la debilidad de Yussef por ser reconocido y amado por su pueblo. Con motivo de la fiesta de fin de ramadán, dijo Lyautey: "Se ha mostrado [el sultán] muy sensible a la calificación de jerife soberano y a la alusión a la ovación hecha en París a los soldados marroquíes durante el desfile del 14 ”. No sin razón, el mariscal galo puede ser considerado el máximo sostén de los alauitas en la época. Lyautey controlaba los movimientos del sultán y le había hecho aceptar que sólo visitaría las capitales imperiales cada dos años. La cordialidad e incluso la simpatía entre Yussef y Lyautey estaban encima de la mesa. Al fin y al cabo, Muley Yussef le debía el trono, y Lyautey al sultán, su poder virreinal, al haberlo salvado de las complicadas relaciones políticas parisinas donde se exigía frecuentemente su cabeza. Para completar el cuadro, la entrega de Muley Yussef a la causa de los aliados queda fuera de duda, ya que éste habría de felicitar públicamente la colaboración anglofrancesa contra el eje liderado por Alemania.

En todo este laberinto, el argelino Ben Ghabrit siguió teniendo un papel esencial, no sólo en temas aparentemente banales, como continuar siendo el encargado de las compras de novedades, desde un vehículo hasta máquinas de coser, para el sultán reinante, sino sobre todo en la tramoya de un tema mayor, como la construcción de la gran mezquita de París.

Como parte del cuadro final que escenifica la relación del majzén jerifiano con Francia, en julio de 1926, en coincidencia con el final del periodo lyauteyano en Marruecos, pero con Lyautey y Ghabrit en la trastienda de todo, se preparó el viaje de Muley Yussef a París, que haría en el crucero París, desde Casablanca a Toulon, donde sería recibido con grandes honores (Maroc. Le sultan et les personnalités marocains. Voyage du sultan en France, junio-noviembre de 1929). El motivo principal del viaje sultanesco fue la inauguración de la gran mezquita de París. Se deseaba un acto esencialmente religioso islámico, pero coincidente con la celebración de la fiesta nacional francesa del 
14 de julio (González Alcantud, 2015). Para dar más realce a la visita, lo acompañaría su vistosa guardia negra.

Un asunto que creó un poco de tensión fue la coincidencia en París, con motivo del 14 de julio, del bey de Túnez y del sultán de Marruecos. Como este último reclamaba ser el "califa" de los musulmanes del norte de África, exigió que el viaje del tunecino disminuyera en importancia con el fin de no hacerle sombra. No debían juntarse sus caminos más que cuando se hubiera inaugurado la mezquita, honor que se reservaba a Muley Yussef.

Argelinos y españoles fueron marginados de la inauguración. Los primeros estuvieron muy molestos con el papel de su conciudadano Ghabrit, al servicio de Marruecos y de Francia, al que no reconocieron como "representante del islam". El general Primo de Rivera, que en los mismos días estaba en $\mathrm{Pa}$ rís para firmar el acuerdo de paz del Rif, tras la guerra con Abdelkrim al Jatabi, asistió a la recepción que el ayuntamiento de París reservaba al sultán marroquí, pero no fue invitado a la ceremonia de inauguración de la mezquita parisina. El papel destacado que Francia dio al "comendador de los creyentes" Muley Yussef, concuerda con el deseo de disminuir la influencia española en Marruecos y así evitar cualquier obstáculo para manipular, en tanto "nación musulmana", el califato del norte de África.

\section{La "supervivencia" de la teoría segmentaria}

Se observa, con el devenir de los tres sultanes coetáneos de Marruecos, y sobre todo del periodo conflictivo entre ellos que va de 1909 al final de la guerra europea, que las potencias apostaron por obtener ventajas de su delicada situación. Jugaron con ellos a sabiendas de que la constitución interna de la estructura sociopolítica jerifiana era "segmentaria", y que sobre ella imperaba el carácter místico de la institución de la sultaniya, expresión de la idea nunca abolida del todo del "califato". Francia, como "nación musulmana" que pretendía ser, quería liderar el "califato occidental". La legitimidad que esgrimió se vio sustentada por los acontecimientos que precedieron y 
siguieron a la inauguración de la gran mezquita de París en 1926, en los que el sultán marroquí aparecía claramente como el único chorfa norafricano capaz de ostentar una genealogía que provenía del Profeta. Todo esto frente a las pretensiones del califato turco, aliado de Alemania, y del califato árabe, tutelado por los ingleses.

Por otra parte, las lógicas de fondo eran puramente segmentarias en el propio ámbito nacional si tenemos presente que los nuevos "linajes" que entraban en concurso disputándose el poder metropolitano o nacional eran grupos que no respondían sólo a intereses nacionales homogéneos. Lyautey y su "tribu" necesitaban tanto a los alauitas, sobre todo a Muley Yussef a la vista del fracaso de Abdulaziz y Hafid, como ellos a él frente a las "tribus" parisinas que no dejaban de pedir su cabeza. Unos y otros se apoyaban en grupos de presión y tenían que hacer alianzas y contraalianzas cruzadas, basadas en el interés.

El hecho relatado, el periodo de los tres sultanes que va de 1894 a 1927, muy poco explorado en sus últimas consecuencias en las historiografías marroquí, francesa y española, solamente puede ser interpretado en toda su significación a la luz de una antropología histórica, sacada de la sencilla dialéctica colonizado/colonizador, que no puede darnos las claves. El juego político de los tres sultanes mencionados tenía prolongaciones intencionadas, en las que prosperaban las tensiones entre potencias coloniales y entre fracciones coloniales y locales, donde los factores de desestabilización entre el majzén y las tribus eran crónicos.

Además, el debate sobre segmentariedad no es exclusivo de las sociedades norafricanas, como la antropología clásica estructural funcionalista quiso hacernos ver. Tampoco fue rechazado el concepto, como ocurrió entre un sector de la historia y la antropología y la historia magrebíes, por "colonial”, por querer ver los estudiosos occidentales estructuras tribales donde no las había, con la finalidad "aplicada" de ejercer el "divide y vencerás” tribal de altos beneficios político-coloniales.

La segmentariedad remite al concepto de "enemistad", categoría que Carl Schmitt (1992) veía como central en la constitución del hecho político. No cabe negar la teoría de la segmentariedad como una proyección de la ciencia colonial, sino 
extender su concepto más allá, incluso al ámbito de las relaciones internacionales. La "tribalidad" no sería de esta manera un concepto prepolítico, como pretende K. Popper (2010), sino un hecho más universal de lo que pensábamos hasta ahora.

La novedad de nuestra aportación reside en el nuevo marco internacionalizado de la "segmentariedad" política y su nueva significación más allá de lo estrictamente local. Con esto la teoría segmentaria se actualiza y migra de lo tribal a lo global. En cierta forma, viene a ser una alternativa a posturas que ven en el tránsito entre el mundo colonial y el nacionalismo la existencia de dos mundos en discontinuidad (Bernard, 1968). La continuidad se la da la segmentación.

Dirección institucional del autor:

Facultad de Filosofía y Letras

Departamento de Antropología Social

Universidad de Granada

Campus de la Cartuja s/ $n$

18071, Granada, España

\section{Referencias}

AbDessalam, C. (2013). En passant par Tombouctou: l'épopée de Moulay Hiba, sultan insurrectionnel anticolonial, roi de Marrakech et du Sahara, 1912. París: Alfabarre.

Aubin, E. (2004). Le Maroc dans la tourmente, 1902-1903. París: ParisMediterranée.

BAzZAz, S. (2010). Forgotten saints. History, power, and politics in the making of modern Morocco. Cambridge, MA: Harvard University Press.

Benoist-Méchin, J. (1994). Histoire des Alaouites (1268-1971). París: Perrin.

BERnARD, S. (1968). The franco-maroccan conflict, 1943-1956. New Haven, CT: Yale University Press.

Cefaï, D. (2003). Le souk de Sefrou. Analyse culturelle d'une forme sociale. En Clifford Geertz. Le souk de Sefrou. Sur l'économie du bazar (pp. 7-53). París: Éditions Bouchène.

DJAÏт, H. (1989). La grande discorde. Religion et politique dans l'Islam des origines. París: Gallimard. 
DoutTÉ, E. (1909). Le sultanat marocain. Revue Politique et Parlementaire.

Eickelmann, D. F. (2003). Antropología del mundo islámico. Barcelona: Bellaterra.

El Mezouari el Glaoui, A. (2016). Le grand vizir Madani el Mezouari el Glaoui: une vie au service du Makhzen. Casablanca: La Croisée des chemins.

Evans-Pritchard, E. E. (1949). The Sanusi of Cyrenaica. Oxford: Clarendon Press.

Forbes, R. (2010). El Raisuni, sultán de las montañas. Córdoba: Almuzara.

Gellner, E. (1969). Saints of the Atlas. Chicago, CH: University of Chicago Press.

GonzÁlez Alcantud, J. A. (1998). Antropología (y) politica. Sobre la formación cultural del poder. Barcelona: Anthropos.

GonzÁlez Alcantud, J. A. y Corrales, E. M. (Eds.). (2007). La conferencia de Algeciras de 1906: un banquete colonial. Barcelona: Bellaterra.

González Alcantud, J. A. (2010). Masacre y conciencia poscolonial. En torno a las imágenes de la sublevación y pogromo de 1912 en Fez y su olvido. Imago Crítica, (2), 103-134. Recuperado de https://www.academia.edu/15688614/Masacre_y_conciencia_poscolonial._En_torno_a_las_im\%C3\%A1genes_de_la sublevaci\%C3\%B3̈n_y_pogromo_de_1912_en_Fez_y_su_olvido González Alcantud, J. A. (2013a). Poder y ritual en la moñarquía alanita de Marruecos. Discurso a Real Academia de Ciencias Morales y Políticas de España para acreditación como académico correspondiente. Recuperado de http://www.racmyp.es/R/ racmyp/docs/corr/Alcantud\%20discurso.pdf

González Alcantud, J. A. (2013b). El Rogui Bu Hamara y la inestabilidad marroquí en perspectiva española. Una explicación etnohistórica. En F. Benlabbah y A. Barouki (Eds.), La problemática colonial española en Marruecos (pp. 11-46). Rabat: Instituto de Estudios Hispano-Lusos. Recuperado de https://www. academia.edu/12260123/El_Rogui_Bu_Hamara_y_la_inestabilidad_marroqu\%C3\%AD_en_perspectiva_espa\% $\%$ C $3 \%$ B1ola. Ensayo_etnohist\%C3\%B3rico

GonZÁlez Alcantud, J. A. (2014). La crueldad como simbolización del despotismo oriental. El caso de la ejecución del Rogui Bu Hamara en Fez en 1909. En. C. Lisón Tolosana (Ed.), Antropología: horizontes simbólicos (pp. 97-128). Valencia: Tirant. Recuperado de http://www.academia.edu/12260231/La_crueldad_como_ 
simbolizaci\%C3\%B3n_del_despotismo_oriental._El_caso_de la_ejecuci\%C3\%B3n_del_Rogui_Bu_Hämara_en $\overline{\text { Fez }} \overline{\text { en }}$ en $\overline{1}$ - $90 \overline{9}$ GonzÁLez Alcantud, J. A. (2015). La gran mezquita de París. Un proyecto político de arquitectura mauresque en la Francia de las exposiciones universales y coloniales. Awraq. Revista de análisis y pensamiento sobre el mundo árabe contemporáneo, (11), 99-122. Recuperado de http://www.awraq.es/blob.aspx?idx = 5\&nId = 128\&hash $=1 \mathrm{cfee} 8 \mathrm{cc} 9 \mathrm{c} 716674114 \mathrm{~d} 1727379 \mathrm{f} 16 \mathrm{f} 8$

Hammoudi, A. (1974). Segmentarité, stratification sociale, pouvoir politique et sainteté. Refléxions sur les thèses de Gellner. Hespéris-Tamuda, 15, 147-179. Recuperado de http://www.hesperistamuda.com/index.php/archives/archives-1970-1979/241hesperis-tamuda-1974

Hammoudi, A. (1999). The reinvention of 'Dar al muluk: The Moroccan political system and its legitimation. En R. Bourqia y S. Gilson Miller (Eds.), In the shadow of the sultan. Culture, power, and politics in Morocco (pp. 129-175). Cambridge, MA: Harvard University Press.

Hammoudi, A. (2007). Maestro y discípulo. Fundamentos culturales del autoritarismo en las sociedades árabes. (Trad. P. Lévy). Barcelona: Anthropos.

HARRIS, W. B. (2012). Le Maroc disparu: anecdotes sur la vie intime de Moulay Hafid, de Moulay Abd el Aziz, et de Raissouli. Casablanca: Dar al Amane.

HART, D. M. (1999). Ibn Jaldún y Evans-Pritchard: la solidaridad agnática y la segmentariedad en la teoría y la práctica de la antropología sociocultural del mundo islámico. En D. M. Hart y R. Raha Ahmed (Eds.), La sociedad bereber del Rif marroquí. Sobre la teoría de la segmentariedad en el Magreb (pp. 11-52). Granada: Universidad de Granada.

Hicham el Alaui, M. (2014). Journal d'un prince banni. Demain, le Maroc. París: Grasset.

Houel, C. (2014). Mes aventures marocaines. Casablanca: Casa express. JALDÚN, I. (1977). Introducción a la historia universal (Al-Muqaddimab). México: Fondo de Cultura Económica.

JustinaRD, C. (2015). Un grand chef berbère. Le caïd Goundafi. Rabat: Dar al aman.

Kably, M. (Ed.). (2012). Histoire du Maroc. Réactualisation et synthèse. Rabat: Institut Royal pour la Recherche sur l'Histoire du Maroc. Katz, J. G. (2006). Murder in Marrakesh: Émile Mauchamp and the French colonial adventure. Bloomington: Indiana University Press. 
LAROUI, A. (1993). Les origines sociales y culturelles du nationalisme marocain, 1830-1912. Casablanca: Centre Culturel Arabe.

Leveau, R. (1985). Le fellah marocain défenseur du trône. París: Presses de la Fondation Nationale des Sciences Politiques.

Martinière, H.-M.-P. de la y Lacroix, N. (1984). Documents pour servir à l'étude du Nord-Ouest africain (T. I). Alger: Gouvernement général de l'Algérie.

Maxwell, G. (2004). Lords of the Atlas. The rise and fall of the House of Glaoua 1893-1956. Londres: Eland.

Michaux-Bellaire, É. (1908). Au palais du Sultan marocain. Revue du monde musulman, 5, 647-662.

MichauX-Bellaire, É. (1925). La souveraineté et le Califat au Maroc. Revue du Monde Musulman, 59, 117-145.

Millán Astray, J. (12 de octubre de 1918). Los reyes en el exilio. El Heraldo de Melilla.

Montagne, R. (1930). Les Berbères et le Makbzen dans le sud du Maroc: essai sur la transformation politique des Berbères sédentaires (groupe chleub). París: Félix Alcan.

Mouline, N. (2016). Le califat. Histoire politique de l'Islam. París: Flammarion.

OtTmani, H. B. D. (2010). Kaddour Benghabrit. Un maghrébin hors du commun. Rabat: Marsam.

Popper, K. (2010). La sociedad abierta y sus enemigos. Barcelona: Paidós.

Rabinow, P. (1992). Reflexiones sobre un trabajo de campo en Marruecos. Madrid: Júcar.

RACHIK, H. (2012). Le proche et le lointain. Un siècle d'anthropologie au Maroc. Marsella: Parenthèses.

Rivet, D. (1988). Lyautey et l'institution du Protectorat français au Maroc, 1912-1925 (3 Vols.). París: L’Harmattan.

ROBERTSON SMITH, W. (1909). Kinship and marriage in early Arabia. Londres: Adam and Charles Black.

Sснмітт, C. (1992). La notion de politique. Théorie du partisan. París: Flammarion.

Telhine, M. (2010). L'Islam et les musulmans en France. Une histoire de mosquées. París: L'Harmattan.

Teyssier, A. (2004). Lyautey : le ciel et les sables sont grands. París: Perrin.

Tharaud, J. y Tharaud, J. (1920). Marrakech ou les seigneurs de l'Atlas. París: Plon.

Tharaud, J. y Tharaud, J. (1925). Rendez-vous espagnols. París: Plon. Tozy, M. (2008). Monarchie et islam politique au Maroc. París: Presses de Sciences Politiques. 
Una conversación con Muley Hafid (15 de febrero de 1920). $A B C$, p. 13. Recuperado de http://hemeroteca.abc.es/nav/Navigate. exe/hemeroteca/madrid/abc/1920/02/15/013.html

Veyre, G. (2008). Dans l'intimité du sultan. Au Maroc (1901-1905). Casablanca: Afrique Orient.

Waterbury, J. (1975). Le Commandeur des croyants. La monarchie marocaine et son élite. (Trad. C. Aubin). París: Presses Universitaires de France.

Weisgerber, F. (1947). Au seuil du Maroc moderne. Rabat: Éditions La Porte.

\section{Materiales de archivo}

Hafid, M. [mecan.]. El asedio de Fez por las cabilas. 1911: la agonía del Imperio marroquí. Biblioteca Nacional de España, fondo antiguo, MSS/22902.

Information-Presse-Propagande-Service d'information et de presse 1914-1940. Archives diplomatiques, Paris La Courneuve, Archives du Ministère des Affaires Étrangères, fond 229QO, vol. 17.

Information-Presse-Propagande-Service d'information et de presse 1914-1940. Archives diplomatiques, Paris La Courneuve, Archives du Ministère des Affaires Étrangères, fond 229QO, vol. 49.

Information-Presse-Propagande-Service d'information et de presse 1914-1940. Archives diplomatiques, Paris La Courneuve, Archives du Ministère des Affaires Étrangères, fond 229QO, $45 \mathrm{ca}-52$.

Los sultanes de Marruecos [ms.]. Biblioteca Nacional de España, fondo antiguo, AFRC/7066/4.

Maroc affaires diplomatiques. Politique générale [1908]. Archives du ministère des Affaires étrangères, La Courneuve. Correspondance politique et commerciale (1918-1940), série K-Afrique, Maroc, cote 73CPCOM, vol. 1.

Maroc affaires politiques. Politique générale XV [1909]. Archives du ministère des Affaires étrangères, La Courneuve. Correspondance politique et commerciale (1918-1940), série K-Afrique, Maroc, cote 73CPCOM, vol. 3.

Maroc. Le sultan et les personnages [corrigé “personnalités”] marocains, les anciens Sultans. Moulay Abd el Hafid (mayo de 1921abril de 1922). Archives du ministère des Affaires étrangères, La 
Courneuve. Correspondance politique et commerciale (19181940), série K-Afrique, Maroc, cote 73CPCOM, vol. 5.

Maroc. Le sultan et les personnages marocains (1917-1927). Archives du ministère des Affaires étrangères, La Courneuve. Correspondance politique et commerciale (1918-1940), série K-Afrique, Maroc, cote 73CPCOM, vol. 1.

Maroc. Le sultan et les personnages marocains, les anciens sultans Moulay Abde el Hafid (1917-1920). Archives du ministère des Affaires étrangères, La Courneuve. Correspondance politique et commerciale (1918-1940), série K-Afrique, Maroc, cote 73CPCOM, vol. 4.

Maroc. Le sultan et les personnalités marocains. Les anciens sultans (marzo de 1922-diciembre de 1924). Archives du ministère des Affaires étrangères, La Courneuve. Correspondance politique et commerciale (1918-1940), série K-Afrique, Maroc, cote 73CPCOM, vol. 6.

Maroc. Le sultan et les personnalités marocains. Voyage du sultan en France (junio-noviembre de 1929). Archives du ministère des Affaires étrangères, La Courneuve. Correspondance politique et commerciale (1918-1940), série K-Afrique, Maroc, cote 73CPCOM, vol. 20.

Maroc. Le sultan et les personnages [corrigé "personnalités") marocains, les anciens sultans Moulay Abde el Aziz (1917-1937). Archives du ministère des Affaires étrangères, La Courneuve. Correspondance politique et commerciale (1918-1940), série KAfrique, Maroc, cote 73CPCOM, vol. 3.

Résidence générale de la république française au Maroc (enero-julio de 1918). Rapport mensuel d'ensemble du Protectorat, Marruecos, Direction du Service des renseignements. Archives Nationales D'Outre-mer, Aix-en-Provence, Ministère des Colonies, Direction des Affaires politiques/Maroc/Administration générale de la colonie/Affaires politiques/1907-1918,1AFFPOL/899/1.

Résidence générale de la république française au Maroc, Fonds Ministériels. Documents internes. Marruecos, Renseignements politiques 1955-1956, Maroc espagnol et Tanger. Archives Nationales D'Outre-mer, Aix-en-Provence, Ministère des Colonies, Direction des Affaires politiques/Maroc/Administration générale de la colonie/Affaires politiques/1911-1920, FM 1AFFPOL/905/1. 